\section{"More research needed"}

\section{Washington}

THE Bush administration, under fire from environmentalists for its reluctance to embrace global warming countermeasures, believes that two more years of research is needed before the science of climate modelling is strong enough to dictate environmental policy, said Energy Secretary James Watkins in an interview last week.

By 1992, "our national laboratories are going to have enough answers for us to get specific" about climate predictions, Watkins said. The administration reckons it will be spending half the worldwide total on climate change research in 1991; Department of Energy (DOE) research alone accounts for $\$ 66$ million of the request.

Although several European countries have already begun programmes that would restrict the emission of carbon dioxide and other greenhouse gases to current levels, Watkins said recent scientific advances still cannot "economically justify taking drastic steps" to control emission in the United States. But he believes that the moderate measures already in place can have a significant impact on greenhouse gas concentrations. "We're going after all the knowns, such as acid rain, the ozone layer, and deforestation, while we wait for the science clarification" on global warming, he said: efforts such as the phasing out of clorofluorocarbons, along with new energy-efficiency initiatives, can cut greenhouse gas emission by about a quarter in the next decade.

Speaking a week after President Bush opened a United Nations meeting on climate change by calling cautiously for more research, without accepting predic-

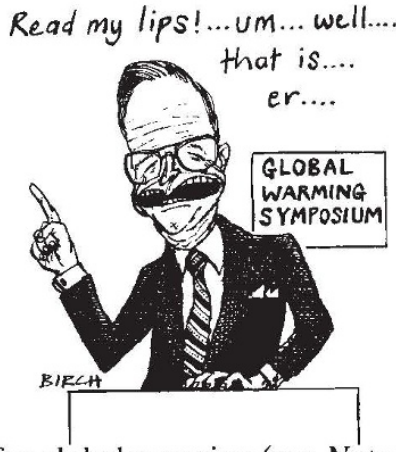

tions for global warming (see Nature 343, 500 ; 8 February 1990), Watkins acknowledged that DOE's own experts do indeed forecast a global temperature rise from present predictions of the increase in carbon dioxide. "I believe that there is a greenhouse gas increase, and infrared absorption [by those gases]. The [DOE] labs clearly say that the greenhouse effect is generated under those circumstances," he said. But, he added, do "we have to destroy the industrial base and our economy for world survival?"

"Although he said he is "not against the thrust" of minimizing greenhouse gas generation, he objected to "premature" congressional bills by Senator Tim Wirth (Democrat, Colorado) and Representative Claudine Schneider (Republican, Rhode Island) that would require a 30 per cent reduction in carbon dioxide emissions by the end of the century. "To solve something out of the hip pocket like that in an election year may be attractive, but I think it is not the responsible approach", Watkins said.

Watkins believes that increased use of hydroelectric power and "biomass" fuels such as ethanol could fulfil three quarters of the new energy needs in the next decade. "Perhaps with those two things and conservation, we could get very close to hold- ing the line on current emissions" without imposing additional controls on industry, he said. Conservative administration officials such as White House chief of staff John Sununu have fought bitterly against new industrial emissions regulations.

In private debate within the administration, Watkins is said to side occasionally with William Reilly, the director of the Environmental Protection Agency, who has seemed to fret against the cautious approach of the Bush administration. But in public Watkins remains mindful of the party line. He refuses to use the term "global warming", for example, preferring to talk about "climate change".

"Obviously there are some environmentalists who are never going to be satisfied [with administration polices]. But we're trying to cut a wide swath down the middle of this thing and I think we're doing a pretty good job of it", he said.

G. Christopher Anderson

\title{
Applications under review
}

\section{Tokyo}

THIS week, international committees of scientists in Strasbourg will begin reviewing a flood of hundreds of applications from scientists around the world to Japan's Human Frontier Science Program which was established as a foundation in Strasbourg last November.

Frontiers, which is funded almost entirely by the Japanese government, provides grants for international teams of scientists, fellowships and support for workshops for research on the brain and molecular recognition. The programme is open to applicants from any country in the world but the principal researcher for grants must belong to one of the seven summit nations (United States, Canada, United Kingdom, West Germany, France, Italy and Japan) or a non-summit European Community (EC) nation. And fellowship applicants from non-summit nations must carry out their research in a summit nation (summit nation fellowship applicants can go to any country they wish other than their own).

Frontiers is proving very popular. Eight hundred and twenty-five scientists from 33 countries have made 236 applications for the approximately $20 \$ 500,000$ three-year grants available this fiscal year. And 210 young scientists have applied for the 100 long-term fellowships (but only ten have applied for the 50 short-term fellowships). There are also 35 applications for support for workshops, ten of which will be accepted.

Applications will be screened by four committees each comprising 16 eminent scientists (two from each summit nation and two from the EC). Two committees (one for brain research, and one for molecular research) will screen the grant applications after a preliminary peer review by mail, and the other two committees will review the fellowship and workshop applications. The awards are expected to be announced in the middle of March after approval by the programme's council of scientists.

Ironically, it is countries contributing no financial support to Frontiers that stand to gain the most if the awards reflect the distribution of applications. The biggest number of grant applications (66) comes from principal scientists based in the United States as does the biggest number of fellowship applications (66). The United Kingdom also has a large number of applicants for grants (47) and fellowships (26). Japan, with 56 grant and 38 fellowship applications, fares comparatively badly considering that Japan is financing most of the programme.

Another feature apparent from the applications is that the United States is by far the most popular destination for fellowship applicants. More than half the applicants (107) want to go to there. On the other hand, only ten young scientists want to go to Japan and nearly four times as many want to leave (38).

Toichi Sakata, director of the Frontiers office at the Science and Technology Agency (STA), hopes that more countries will agree to contribute funds to the programme now that the framework for Frontiers is complete and nations can see how it works. He says the lack of fellowship applicants to Japan is disappointing and STA will take measures to publicize the strengths of Japan's research system to try to attract more foreign scientists.

David Swinbanks 